\title{
WIDESPREAD OF TRICHOGRAMMA EGG PARASITOIDS AMONG MANGROVE FORESTS, AVICENNIA MARINA
}

\author{
Abdel-Rahman, Abdel-Rahman G. ${ }^{1}$, Esam Agamy ${ }^{2}$, Mohammed \\ Foud $^{3}$, Usama M. Abu El Ghiet ${ }^{2}$ \\ ${ }^{1}$ Department of Plant Protection, Desert Research Center, Cairo, Egypt \\ ${ }^{2}$ Department of Economic Entomology and Pesticides, Faculty of \\ Agriculture, Cairo University \\ ${ }^{3}$ Zoology Department, Faculty of Science, Al-Azhar University, Cairo, \\ Egypt \\ ${ }^{4}$ Economic Entomology Unit, Department of Plant Protection, Desert \\ Research Center, and Biological Department, Faculty of Science, \\ Jazan University, KSA \\ *E-mail: ag.rahman50@gmail.com
}

\begin{abstract}
vicennia marina is one of the common features of the $A$ vegetation of the littoral landscape of Red Sea, Egypt, and considers as protected area with unauthorized use of pesticides. The carob moth Ectomyelois ceratoniae (Family Pyralidae) and the mangrove plumemoth Cenoloba obliteralis (Family Tineodidae) are common herbivores on mangrove forests in Egypt. The present study aimed to search of indigenous Trichogramma spp. within mangrove forests and also to evaluate the distribution of the three Trichogramma species; T. cordubensis, $T$. bourarachae and $T$. cacoeciae through mangrove forests when they were released in mangrove swamps as bio-control agents. In general, releasing parasitoids allowed them to move towards the East and South directions. The distance was 3 meters where most of the released individuals prefer to move to 1 or 5 meters. T. cordubensis was the highest potent egg parasitoid that has the ability to be released in an inundative manner to combat lepidopteran pests attacking mangrove forests in Egypt.
\end{abstract}

Keyword: Trichogramma cordubensis, T. bourarachae and T. cacoeciae, directional and distance distributions, mangrove forests

Mangrove forests comprise trees and shrubs belonging to 68 species, within 12 genera in 8 families (Nybakken, 1993). Three mangrove species are The $1^{\text {st }}$ Conference of Plant Protection Science Applications for Sustainable Development of Desert Areas "Effect of Climate Change on Plant Pests and Biodiversity in Desert Environment" 19-20 October, 2019, Cairo-Egypt. 
recorded along the African Red Sea coasts namely Avicennia marina, Rizophora mucronata and Bruguiera gymnorrhiza (Kassas and Zahran, 1967). Many insects are associated with mangrove plants. Some are pollinators and beneficial natural enemies; others are pests, visitors or insects of medical importance. Murphy (1990) described 102 insect herbivores that attack 21 mangrove species in Singapore. Veenakumari et al. (1997) listed 197 species of herbivores on the Andaman and Niicobar islands. At two mangrove localities in the Egyptian Red Sea coast, Abdel-Rahman et al. (2006) reported that 78 species, 69 genera in 46 families, belonging to 11 orders of class Insecta were captured by the light trap in mangrove forests. Some of them were beneficials while others were pests. These insect pests can cause damage to mangrove swamps being herbivores, borers and seed pests. The two lepidopteran species; carob moth Ectomyelois ceratoniae (Family Pyralidae) and the mangrove plume moth Cenoloba obliteralis (Family Tineodidae) were the most serious and common herbivores on A. marina forests in Egypt (Abu El-Ghiet, 2006 and 2011). Field release of commercial strains of the egg parasitoids Trichogramma is considered as a promising approach in the biological control of many lepidopteran pests (Smith, 1996; Agamy, 2007 and Abdel-Rahman et al., 2008). One of the most important points that must be considered before designing any control program depending on a biological candidate is to seek, try to catch, mass rearing and finally release the local (indigenous) bio-agent (Agamy, 1994). The present study aimed to search for indigenous Trichogramma spp. within mangrove forests and also to evaluate the distribution of the three collected Trichogramma species; T. cordubensis, T. bourarachae and T. cacoeciae through mangrove forests when they were released in mangrove swamps as biological control agents against lepidopteran pests.

\section{MATERIALS AND METHODS}

\section{Description of the Study Site}

The fringing mangroves A. marina (Family Avicenniaceae), site naturally growing at km-17 south of Safaga, ranged in width from 50 to 100 $\mathrm{m}$ and were bordered on its landward side by mud flats and on its seaward side by salt marsh and sea-grass beds. The mangrove trees in this site were healthy trees, the swamps extended about $800 \mathrm{~m}$ parallel to shoreline and the height of the plants averaged from 1.5 to $4 \mathrm{~m}$.

\section{Searching for Indigenous Trichogramma Parasitoids}

Searching for the Trichogramma parasitoids was mainly done using particular baiting devices, which were consisted of small plastic frames $(3 \mathrm{x}$ $3 \mathrm{~cm}$ ), covered from both sides with fine nylon mesh to allow access of small Trichogramma-wasps, but to prevent predation on the content inside. A small piece of paper with sentinel eggs (Sitotroga cerealella Olivier) glued on was 
inserted in each device (Sakr et al., 2000) (Fig. 1). The device was fixed with a piece of wire close to the mangrove tree branches (Hegazi et al., 2005). Sixty baiting devices were distributed on 12 randomly selected patches in the study area. Depending on insect abundance and fruiting seasons, examinations started in March and expanded to late October 2007 and sentinel eggs were examined and replaced weekly.

\section{Wide Spread of Trichogramma Egg Parasitoids}

Three local egg parasitoids of Trichogramma species; T. cordubensis (T1), T. bourarachae (T2) and T. cacoeciae (T3), previously collected from the Egyptian environment, were weakly released to determine their efficacy to widespread among the mangrove forest, A. marina during the period from 23 April to 11 September 2008. In order to study the recapturing ability of released Trichogramma spp., twelve mangrove patches were chosen randomly. The egg parasitoids were released as pupae inside its factitious host, angoumois grain moth Sitotroga cerealella eggs, which were able to produce about 400 adult female wasps. Releases were applied into the field within thick paper cards to protect the parasitoids from indigenous predators and unfavorable environmental factors. Cards were hanged manually before sunset in the center of each patch and the sentinel eggs (traps) were distributed in three distances $(1,3,5 \mathrm{~m}$ from the Trichogramma cards released points) within the four geographic directions with three replicates in each. At oneweek intervals, new Trichogramma cards were hanged in the same released points while the traps were collected and were replaced with new fresh ones. Collected traps were incubated separately in the laboratory checking for parasitism. Emerged parasitoids were reared in separate glass tubes for identification.
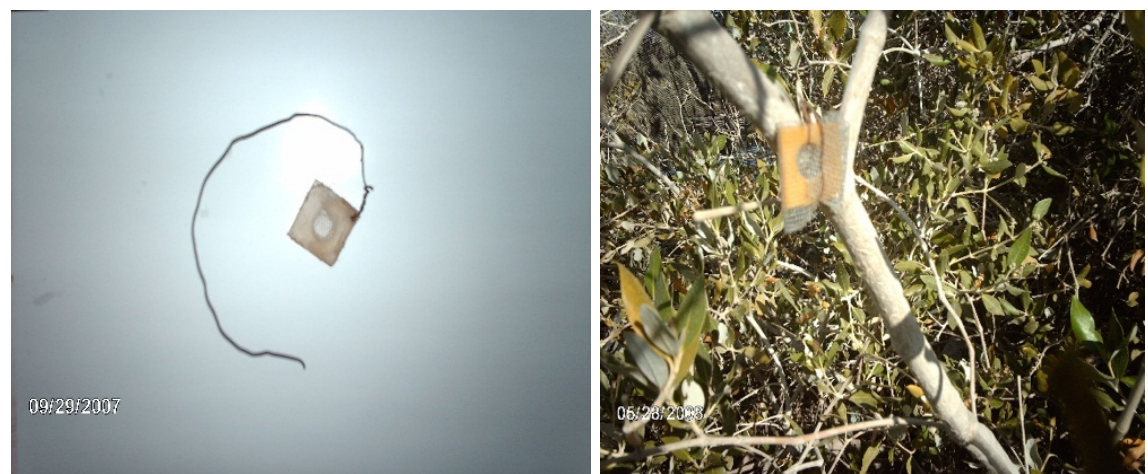

Fig. (1). Trichogramma trap hanged up on mangrove plants. 


\section{RESULTS AND DISCUSSION}

\section{Searching for Indigenous Trichogramma}

During the practical course of this study, the searching for local Trichogramma wasps was extended for about 39 weeks by periodical hanging of Sitotroga egg traps on twelve mangrove patches, then the devices were collected and investigated 7 days later. During this period, Sitotroga egg traps failed to catch any indigenous Trichogramma individual. Accordingly, the sole solution was to examine the activity of certain commercial Trichogramma species that were previously collected from Egyptian fields.

The distribution of released parasitoids inside mangrove forests was represented in tables (1 and 2). Table (1) shows the weekly numbers of the recaptured Trichogramma individuals. The numbers fluctuated along the whole study period between one and five wasps/week with 28 total recaptured parasitoids. The inspection dates 30/4, 28/5, 11/6, 24/7 and 31/7/2008, were the highest recapturing dates as 3, 4, 5, 5 and 4 individuals of the released Trichogramma species succeeded to parasitize the sentinel Sitotroga eggs; respectively. Depending on these pre-mentioned highest recapturing dates, $T$. cordubensis (T1) was the most potent parasitoid species among the three tested egg parasitoids recapturing 2, 4, 5, 2 and 1 individuals. $T$. cordubensis (T1) was the highest recaptured parasitoid with 16 individuals as compared with both $T$. bourarachae (T2) and $T$. cacoeciae (T3) which were represented with only 8 and 4 individuals, respectively. That is $1 / 2$ and $1 / 4$ that of the total re-captured $\mathrm{T} 1$ species individuals.

On the other hand, movement ability and the longest distance that the Trichogramma species can move from their released points in the mangrove forest was declared in table (2). The three released Trichogramma species were recaptured by the Sitotroga egg traps distributed along the three tested distances (1, 3 and $5 \mathrm{~m}$ from the releasing points). For all the tested recapturing distances, $T$. cordubensis (T1) was also the most abundant species as 3, 9 and 4 individuals were recaptured at the three distances, respectively as compared with 2, 5 and 1 and 1, 1 and 2 individuals for the two other species (T2 and T3), respectively. Results in the table also proved that the three meters distance was the most suitable distance for recapturing the tested parasitoids or in other words; it was the distance where most of the releasing individuals prefer to move among. More than $53.5 \%$ of the captured individuals were found at the three meters distanced traps as compared with $21.4 \%$; and $25.0 \%$ were captured at the one- and five-meters distanced traps, respectively. Results in table (2) also showed that in general, released parasitoids prefer to move towards the east and south directions. Of the 28 captured parasitoids, 9 and 8 individuals were found in the traps distributed in the eastern and southern directions of the selected mangrove patches as compared with 6 and 5 individuals in the northern and western ones representing $32.14 \%, 28.57 \%$, $21.43 \%$ and $17.76 \%$ of the total captured individuals in the four geographical

Egyptian J. Desert Res., 69, Special Issue, 165-173 (2019) 


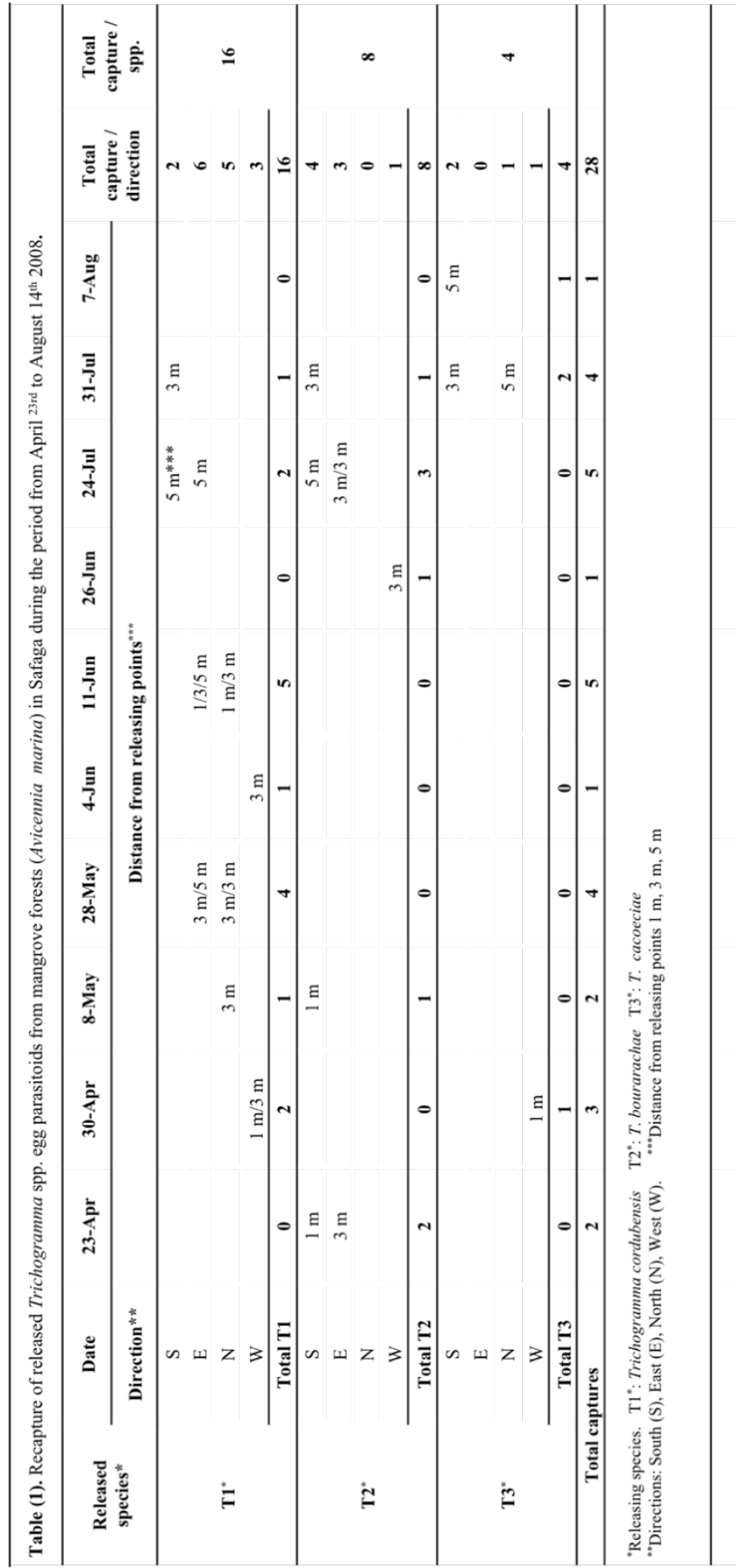

Egyptian J. Desert Res., 69, Special Issue, 165-173 (2019) 
directions (east, south, north and west); respectively. These distributions agreed with the dominant wind direction. According to the available meteorological data during the course of this study, the prevalent wind directions were the east-north and north directions. Concerning the $T$. cordubensis parasitoid (T1); the orientation was slightly different as of the 16 capturing individuals where 6, 5, 3 and 2 individuals oriented themselves towards the south, north, east and west directions, respectively.

Table (2). Directions and distribution distances of Trichogramma spp. through mangrove forests (Avicennia marina) in Safaga during the period from April ${ }^{23 r d}$ to August $14^{\text {th }} 2008$.

\begin{tabular}{|c|c|c|c|c|c|}
\hline $\begin{array}{l}\text { Released } \\
\text { species* }\end{array}$ & $\begin{array}{l}\text { Distance } \\
\text { Direction }^{* *}\end{array}$ & $1 \mathrm{~m}$ & $3 \mathrm{~m}$ & $5 \mathrm{~m}$ & $\begin{array}{r}\text { Total in } \\
\text { direction }\end{array}$ \\
\hline \multirow{5}{*}{$\mathbf{T} 1^{*}$} & $\mathrm{~S}$ & 0 & 1 & 1 & 2 \\
\hline & $E$ & 1 & 2 & 3 & 6 \\
\hline & $\mathrm{N}$ & 1 & 4 & 0 & 5 \\
\hline & $\mathrm{W}$ & 1 & 2 & 0 & 3 \\
\hline & Total & 3 & 9 & 4 & 16 \\
\hline \multirow{5}{*}{$\mathbf{T} 2^{*}$} & $\mathrm{~S}$ & 2 & 1 & 1 & 4 \\
\hline & E & 0 & 3 & 0 & 3 \\
\hline & $\mathrm{N}$ & 0 & 0 & 0 & 0 \\
\hline & W & 0 & 1 & 0 & 1 \\
\hline & Total & 2 & 5 & 1 & 8 \\
\hline \multirow{5}{*}{$\mathbf{T 3}^{*}$} & $\mathrm{~S}$ & 0 & 1 & 1 & 2 \\
\hline & $\mathrm{E}$ & 0 & 0 & 0 & $\mathbf{0}$ \\
\hline & $\mathrm{N}$ & 0 & 0 & 1 & 1 \\
\hline & W & 1 & 0 & 0 & 1 \\
\hline & Total & 1 & 1 & 2 & 4 \\
\hline Total in distance & & 6 & 15 & 7 & 28 \\
\hline
\end{tabular}

${ }^{*}$ T1: Trichogramma cordubensis T2: T. bourarachae T3: T. cacoeciae

${ }^{* *}$ Directions: South (S), East (E), North (N), West (W).

\section{Widespread of Trichogramma Egg Parasitoids}

Biological control agents should preferably be isolated from the relevant pest/crop system, which will be more effective against the target pests and be more tolerant to the prevalent weather conditions than commercially available parasitoid species (Herz and Hassan, 2006). Although, the three tested Trichogramma species were previously isolated from the Egyptian environment, T. cordubensis (T1) was the highest potent egg parasitoid that could find out its way, successfully searching and parasitizing the Sitotroga egg in the traps distributed among the mangrove forests. This may be due to its ability to adapt to the weather conditions characterized the Red Sea coast 
than the other tested species. However, the longest duration and the availability in the fields are not the only factor that give this species the priority to be released in an inundative manner. More information should also be available about the potential of these species and their role to combat lepidopteran pests attacking mangrove forests; this study was already done and now is in process and will be discussed in another work. It is recommended to re-search the mangrove harbored Trichogramma species within the other Egyptian mangrove areas distributed throughout the Red Sea Coast.

\section{REFERENCES}

Abdel-Rahman, A.G., M.A. Fouda, A.S. Bream and U.M. Abo-Elghiet (2006). Diversity of insect fauna associated with mangrove forests naturally growing in the Egyptian Red Sea coasts. Bull. Ent. Soc. Egypt, 83: 167-179.

Abdel-Rahman, A.G., A.M. Abd El-Hafez, B.M. El-Sawaf, B.M. Refaiem and A.I. Imam (2008). Efficacy of Trichogramma evanescens (Westwood) egg parasitoid in suppressing spiny and pink bollworm infestations in El-Farafra cotton fields. J. Biol. Pest Control, 18 (2): 265-269.

Abu El-Ghiet, U.M.H. (2006). Ecological studies on insects associated with mangrove plant naturally growing on the Red Sea Coast, Egypt. M.Sc. Thesis, Fac. of Science, Al-Azhar Univ., Cairo, Egypt.

Abu-Elghiet, U.M. (2011). Studies on certain insect pests attacking mangrove plant and its management. Ph.D. Thesis, Fac. of Science, Al-Azhar Univ., Cairo, Egypt.

Agamy, E. (1994). Comparative studies on three species of Trichogramma for controlling the European corn borer Ostrinia nubilalis HBN. Ph.D. Thesis in Economic Entomology, Joint work between Cairo University and Humboldt University-Berlin-Germany and the German Institute for Biological Pest Control (BBA) DarmtadtGermany.

Agamy, E. (2007). Field evaluation of egg parasitoid, Trichogramma evanescens West. against the olive moth, Prays oleae (Bern) in Egypt. Egypt. J. Biol. Pest Cont., 17 (1/2): 21-27.

Hegazi, E.M., A. Herz, S. Hassan, E. Agamy, W. Khafagi, S. Shweil, A. Zaitun, S. Mostafa, M. Hafez, A. El-Shazly, S. El-Said, L. AboAbdala, N. Khamis and S. El-Kemny (2005). Naturally occurring Trichogramma species in olive farms in Egypt. Insect Science, 12 (3): 185-192.

Herz, A. and S.A. Hassan (2006). Are indigenous strains of Trichogramma sp. (Hym.: Trichogrammatidae) better candidates for biological control 
of lepidopterous pests of the olive tree? Biocontrol Science and Technology, 16 (7/8): 841-857.

Kassas, M. and M. A. Zahran (1967). On the ecology of the red sea littoral salt marsh, Egypt. Ecol. Monogr., 37: 279-315.

Murphy, D.H. (1990). The natural history of insect herbivory on mangrove trees in and near Singapore. The Raffles Bull. Zool., 38: 119-203.

Nybakken, J.W. (1993). Mangroves Forests. In: "Marine Biology". Harper Collins College Publishers, $3^{\text {rd }}$ Ed., pp. 371-386.

Sakr, H.E.A., S.A. Hassan and C.P.W. Zebitz (2000): A new device to capture and monitor the activity of Trichogramma in the field. Mitt. Biol. Bundesanstalt, 376: 578 .

Smith, S.M. (1996). Biological control with Trichogramma: advances, successes, and potential of their use. Annu. Rev. of Entomol, 41: 375406.

Veenakumari, K., P. Mohanraj and A.K. Bandyopadhyay (1997). Insect herbivores and their natural enemies in the mangals of the Andaman and Nicobar Islands. Journal of Natural History, 31 (7): 1105-1126.

Egyptian J. Desert Res., 69, Special Issue, 165-173 (2019) 


\section{نشر طفيل البيض ترايكوجراما خلال غابات الماتجروف}

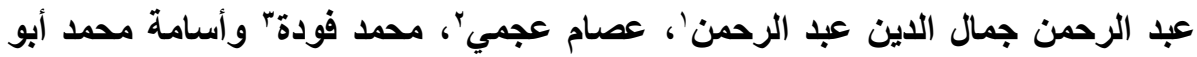

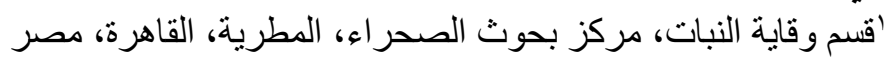

'قنم الغيط؛

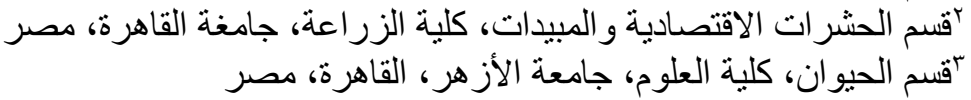

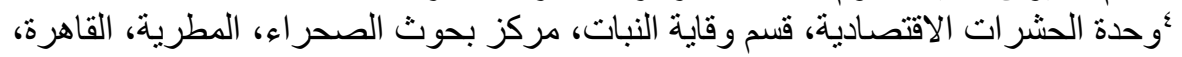
مصر وكلية العلوم، جامعة جيزان، السعودية

تعتبر أثجار المانجروف Avicennia marina واحدة من السمات المعروفة للغطاء

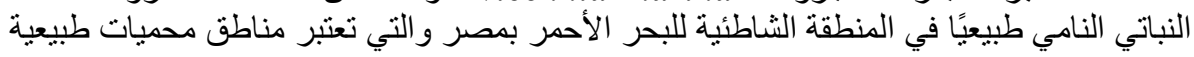

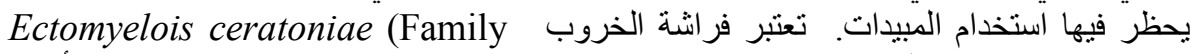
وفر اشة المانجروف Pyralidae)

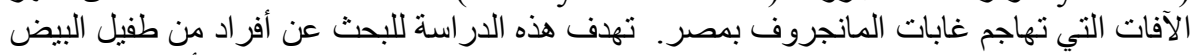

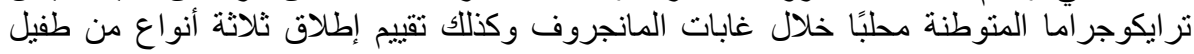

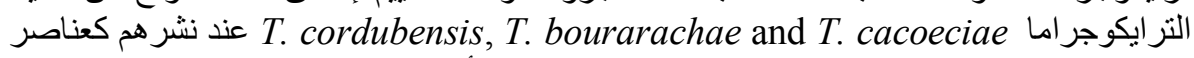

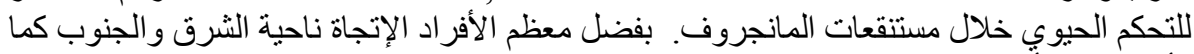

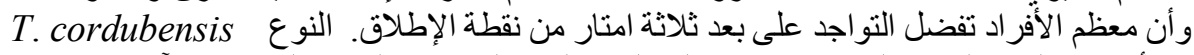

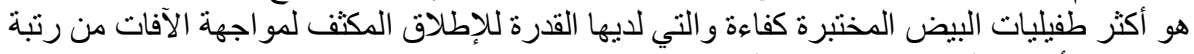

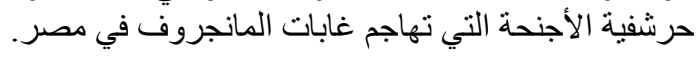

